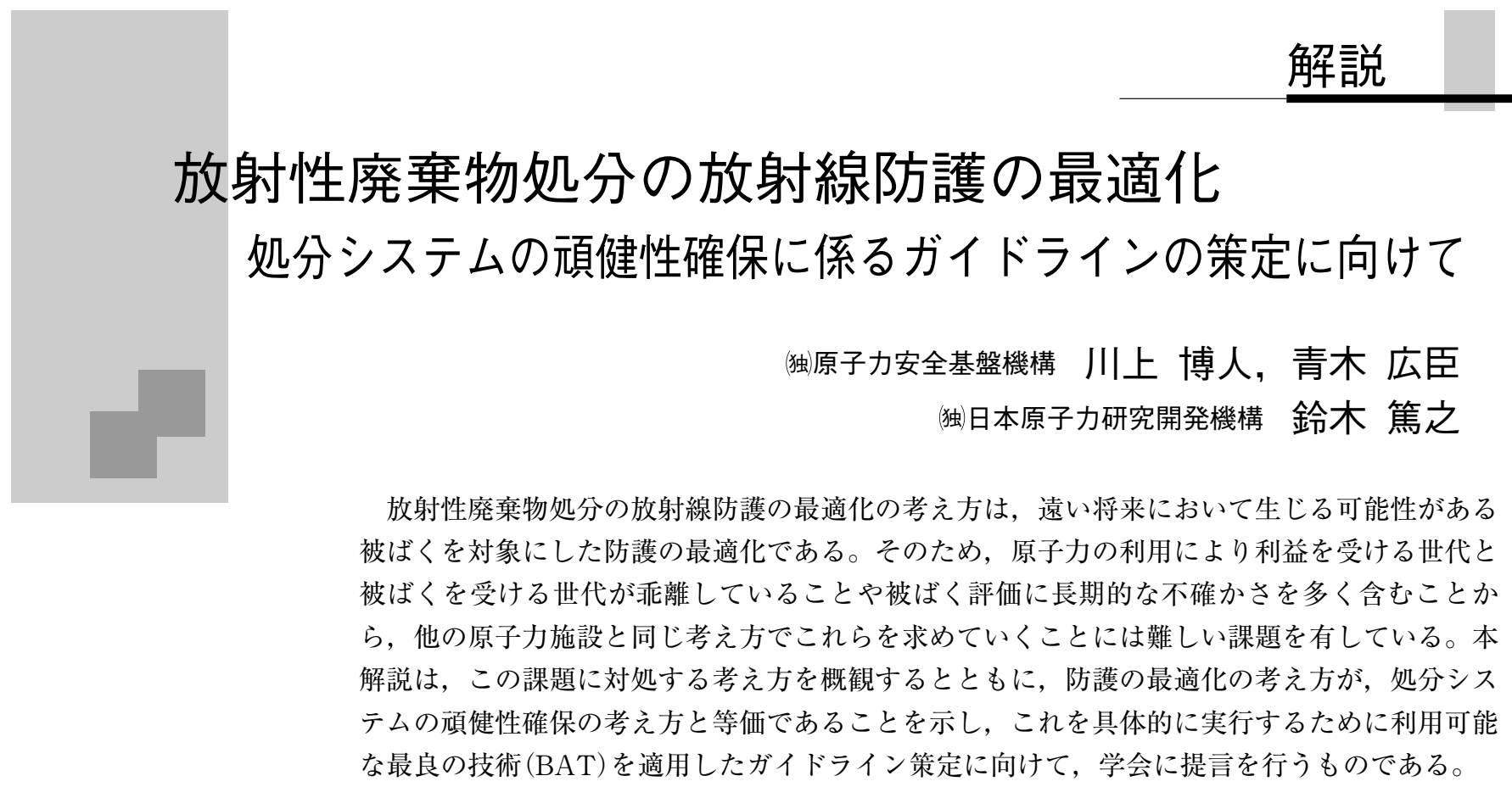

\section{I．背 景}

原子力安全委員会は「余裕深度処分の管理期間終了以 後に打ける安全評価に関する考え方」(以下，「安全評価 に関する考え方」という)を平成 22 年 4 月 1 日付けで委員 会了承した。本報告書の策定過程においては，意見募集 等を通じて放射線防護の専門家等から, 線量のめやすの 考え方や放射線防護の考え方に関し，多くの意見が寄せ られた。この中の主要な論点は，管理期間終了以後の数 十万年にも及ぶ長期的安全評価において，時間とともに 増大する不確かさに対する安全裕度確保の考え方と防護 の最適化の考え方に関するものであった。このような論 点について，議論が集中したのは，我が国において防護 の最適化を安全規制という観点から，どのように具体化 するかといった方法論やその判断基準，特に放射性廃棄 物処分の分野に抢いては, 被ばくの対象となる将来世代 に対する防護の最適化に関する議論がなされて来なかっ たことによるものと思われた。本稿は，このような状況 に鑑み，防護の最適化に係る動向を俯瞰し，防護の最適 化と ALARA (as low as reasonably achievable, economic and social factors being taken into account)の概念 および処分システムの頑健性確保のための考え方が等価 な概念であることを示し，処分システムの頑健性確保に 係るガイドライン策定に向けた学会の動きを期待して, その議論の素材を提供するものである。

The Optimization of Radiation Protection for Radioactive Waste Disposal - A Proposal for Stipulation of Guidelines on Robustness of Radioactive Waste Disposal : Hiroto KAWAKAMI, Hiroomi AOKI, Atsuyuki SUZUKI.

(2010年 7 月 1 日 受理)
II. 我が国の放射性廃棄物処分の安全 規制における防護の最適化

\section{1. 我が国の安全規制における防護の最適化}

我が国においては，原子炉等規制法第51条の 3 におい て，廃棄の事業に関する規制の許可の基準を 3 項目定め ているが，この中で廃異物埋設施設又は廃裹物管理施 設の位置，構造及び設備が核燃料物質又は核燃料物質に よって污染された物による災害の防止上支障がないもの であること。」を求めている。

この具体的な規定については，原子力安全委員会「放 射性廃裹物埋設施設の安全審査の基本的考元方」(以下， 「安全審査の基本的考え方」という）において，管理期間 中と管理期間終了後に分けて記載している。ここで管理 期間とは，廃棄を行う事業者が安全確保のために能動的 な管理を行う事業終了までの期間で，余裕深度処分に埋 設する場合には300年から400年をめやすとしている。こ の中で管理期間中の平常時に扔ける一般公衆の被ばくに ついては，「段階管理の計画，廃棄物埋設施設の設計並 びに敷地及びその周辺の状況との関連において，合理的 に達成できる限り低いものであること」とALARAを要 求し，管理期間終了後の一般公䍃の線量は，「被ばく管 理の観点からは管理することを必要としない低い線量で あること」を求めている。そして解説において，この線 量は，放射線審議会基本部会報告「放射性固体廃棄物の 浅地中処分における規制除外線量について」(昭和62年12 月）に示された規制除外線量である $10 \mu \mathrm{Sv} /$ 年を超えな いことをめやすとすると規定している。

その後，放射線審議会基本部会は上記報告書を改訂 し，「放射性固体廃棄物埋設処分及びクリアランスに係 
る放射線防護に関する基本的考え方について」(平成 22 年 1 月29日）を定めた。この報告書においては，放射線防 護の基本原則の一つである防護の最適化の観点から,「公 衆が将来受ける可能性があるとして評価された被ばく線 量が，以下に示された各規準值を下回る場合でも，当該 被ばく線量が合理的に達成できる限り低くなるよう考慮 が払われるべきであると考える」とし，自然過程に適用 する規準として線量拘束值の $300 \mu \mathrm{Sv} /$ 年を，偶然の人 間侵入に適用する規準として $20 \mathrm{mSv} /$ 年をそれぞれ防護 の最適化の上限值として示した。

「安全評価に関する考え方」は，改訂された上記の放射 線審議会基本部会報告書を反映する形で取りまとめられ たものである。また，原子力安全委員会放射性廃棄物・ 廃止措置専門部会は「安全評価に関する考え方」の策定を 踏まえ，「安全審査の基本的考元方」を改訂し，「第二種 廃棄物埋設の事業に関する安全審査の基本的考え方」(以 下，「安全審查の基本的考え方(改訂)」という)を平成 22 年 8 月 9 日付けで委員会了承した。

\section{2. 余裕深度処分の管理期間終了以後における安 全評価に関する考え方}

余裕深度処分は, 炉内構造物や再処理廃衰物等を埋設 の対象としており, 長半減期核種, 例えば ${ }^{14} \mathrm{C}$ (半減期 : $5.7 \times 10^{3}$ 年), ${ }^{36} \mathrm{Cl}$ (同 : $3.0 \times 10^{5}$ 年)， $\alpha$ 核種等の濃度お よび放射能量が浅地中処分のピット処分対象廃棄物に比 べて高い廃棄物を対象としている。「安全評価に関する 考え方」においては，これら長半減期核種を有意に含む 廃棄物を埋設する場合の安全評価シナリオを 4 種類に区 分し,放射線防護の設計の「めやす」をリスク論的考え方 ${ }^{a)}$ に基づき，その蓋然性に応じて第 1 表のように定めてい る。

この「めやす」, 特に基本シナリオに対する「めやす」 は，防護の最適化の目標值ではなく，不確かさを考慮し

a)すべてのシナリオに対して画一的に放射線防護基準を適用 するのでなく，シナリオ発生の可能性に応じて放射線防護 上の要件に関する充足性を判断する考え方。
た処分システムの設計の妥当性を判断するための「めや す」として示したものである。この管理期間終了以後の 長期的安全評価に係る不確かさに対する安全裕度の取り 方の考え方については，放射性廃棄物処分に固有のリス クと原子炉のそれとの差異を念頭に，第 1 図のような考 え方に基づいている ${ }^{1)}$ 。すなわち，事象の影響である被 ばく線量については，(1)管理が行き届かない長期にわた る被ばくに対する裕度，(3)長期的に増大する不確かさに 対する裕度および(5)長期的安全評価のより大きな仮説に 対する裕度を持たせ，さらに，事象の発生確率について は，(2)安全機能を期待する人工バリアの設計寿命の長期 化および(4)天然バリアに安全機能を期待する期間の長期 化に配慮して，適切な安全裕度を確保する考え方が示さ れている。このように長期的な不確かさに対して適切な 安全裕度を確保することが，処分システムの頑健性確保 に結びついている。

\section{III. 放射性廃棄物処分の国際基準等に おける防護の最適化の考え方}

\section{ICRP における防護の最適化の考え方}

国際放射線防護委員会 (ICRP) は，放射線防護の最適 化については，確率的影響には線量のしきい值がないと いう前提にたち，被ばく線量，被ばくする人の数，被ば くする可能性のある事象の発生確率はできるだけ少ない ほうがよいという考え方に基づき，放射線損害も費用に 換算する防護の最適化の定量的アプローチを進めてき た。ICRP の防護の最適化に係る考え方の変遷を第 2 表 に示す。しかし，放射性廃棄物処分については，将来世 代の集団線量を目標関数にした最適化では，長期的な不 確かさを勘案した場合には，従来の防護の最適化の概念 が適用できないことが認識され，定量的評価よりも定性 的判断が推奨され，その判断のプロセスを重視する傾向 になった ${ }^{2)}$ 。また，「放射線防護の最適化：そのプロセス

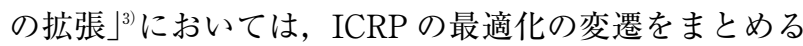
とともに，最適化のプロセスとして，利害関係者の関与 の重要性と最良選択肢の選択の考え方について言及して

第 1 表 安全評価シナリオの区分とその「めやす」

\begin{tabular}{|l|l|c|}
\hline $\begin{array}{c}\text { シナリオ } \\
\text { 区分 }\end{array}$ & \multicolumn{1}{|c|}{$\begin{array}{c}\text { シナリオの内容 } \\
\text { めやす }\end{array}$} \\
\hline $\begin{array}{l}\text { 基本 } \\
\text { シナリオ }\end{array}$ & $\begin{array}{l}\text { 発生の可能性が高く、通常考えられ } \\
\text { るシリオ }\end{array}$ & $10 \mu \mathrm{Sv} /$ 年 \\
\hline $\begin{array}{l}\text { 変動 } \\
\text { シナリオ }\end{array}$ & $\begin{array}{l}\text { 発生の可能性は低いが、安全評価上 } \\
\text { 重要な変動要因を考慮したシナリオ }\end{array}$ & $300 \mu \mathrm{Sv} /$ 年 \\
\hline $\begin{array}{l}\text { 稀頻度事象 } \\
\text { シナリオ }\end{array}$ & $\begin{array}{l}\text { 発生の可能性が著しく低い自然現象 } \\
\text { シナリオ }\end{array}$ & $\begin{array}{c}10 \mathrm{mSv} / \text { 年〜 } 100 \mathrm{mSv} / \\
\text { 人年 }\end{array}$ \\
\hline $\begin{array}{l}\text { シナリオ事象 } \\
\text { シナ }\end{array}$ & 偶発的な人為事象シナリオ & $\begin{array}{c}\text { 周辺住民 : } \\
1 \mathrm{mSv} / \text { 年〜 } 10 \mathrm{mSv} / \text { 年 } \\
\text { 特定の接近者個人 : } \\
10 \mathrm{mSv} \sim 100 \mathrm{mSv}\end{array}$ \\
\hline
\end{tabular}




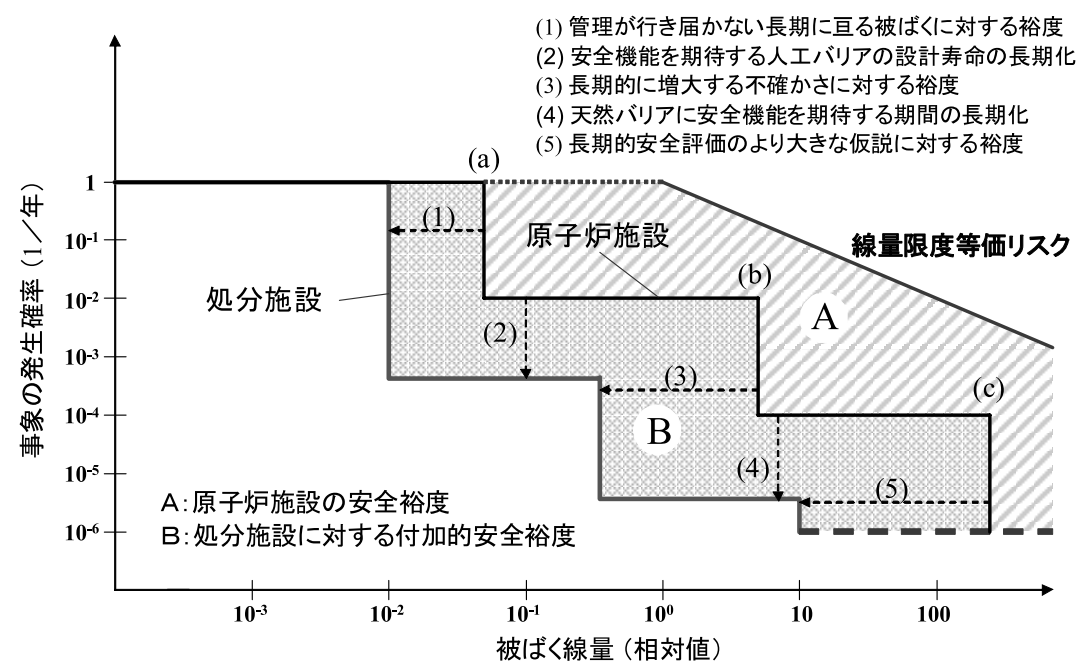

第 1 図 放射性廃棄物処分に固有のリスクと原子炉のリスクとの差異を勘案した安全裕度の考え方

第 2 表 ICRP の放射線防護の最適化に係る考え方の変遷

\begin{tabular}{|c|c|}
\hline ICRPの図書 & 放射線防護のALARA及び最適化の概念の変遷 \\
\hline Publ. 26 : 国際放射 & 放射線防護の3原則と最適化の重要性 \\
\hline 線防護委員会勧告 & $\begin{array}{l}\cdot \text { 放射線防護の } 3 \text { つの原則を歓告 } \\
\end{array}$ \\
\hline （1977年1月17日採 & •費用一便益分析において、独立変数を集囘線量とし、微分 \\
\hline & $\begin{array}{l}\text { 費用一便益分析によって、最適化された集団線量を含む解を } \\
\text { 求める手法を提示。集団線を量を金銭価値に換算する係数とし } \\
\text { て } \alpha \text { 值 }(\$ / \mathrm{manSv}) \text { を導人。 }\end{array}$ \\
\hline Publ. 37 : 放射線防 & 放射線損害の費用の個人線量の大きさに対する依存性と心 \\
\hline 護の最適化におけ & 理的要因 \\
\hline る費用一便益分析 & 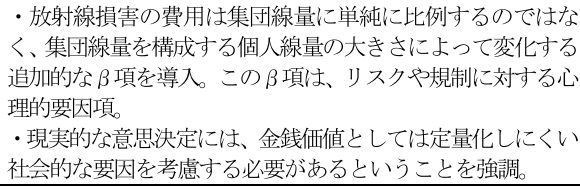 \\
\hline Publ. 55 : 放射線防 & 意思決定への広い適用に向けてより実際的最適化手法の開 \\
\hline $\begin{array}{l}\text { 護における最適化 } \\
\text { と意思決定 }\end{array}$ & $\begin{array}{l}\text { 発 } \\
\text { ·最適化の評価のためには、次に示す四つの定量的意思決定 } \\
\text { 支援手法について具体的な適用例に基づいて説明。 } \\
\text { (1) 費用一効果分析 } \\
\text { (2) 費用一便益分析 } \\
\text { (3) 多属性効用分析 (属性毎に適切な効用関数を設定) } \\
\text { (4) 多基淮優位分析（複数の基淮のもので比較評価） }\end{array}$ \\
\hline Publ.60: 国際放射 & 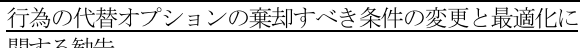 \\
\hline $\begin{array}{l}\text { 線防護委員会の } \\
\text { 1990年御告 }\end{array}$ & 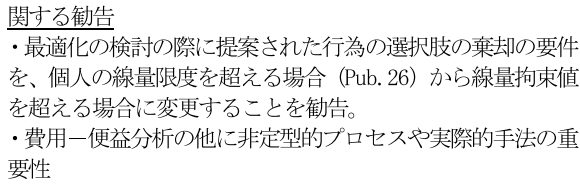 \\
\hline Publ. 77 : 放射性廃 & 長期に亘る低い個人線量とこれに基づく集団線量の最適化 \\
\hline 棄物の処分に対す & の課題 \\
\hline $\begin{array}{l}\text { る放射線防護の対 } \\
\end{array}$ & ·長期に亘る低い個人線量を取扱う防護措置の選択肢の比較 \\
\hline Publ. 101:公衆の防 & 最適化プロセスの拡大 \\
\hline 護を目的とした代 & •最適化のプロセスを整理し、利害関係者の関与の重要性と \\
\hline 表的個人の線量評 & 最良選択肢の選択の考え方に言及 \\
\hline 価・放射線防護の最 & •被ばくの分布を考虑した 3 次元 (空間的分布、時間的分布 \\
\hline $\begin{array}{l}\text { 適化:プロセスの拡 } \\
\text { 大 }\end{array}$ & 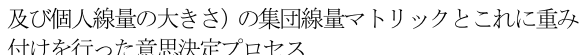 \\
\hline
\end{tabular}

いる。

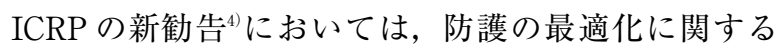
上記の進展を踏まえ，防護の最適化は，経済的および社 会的要因を考慮して，被ばくの発生確率，被ばくする人 の数，および個人線量の大きさのいずれをも合理的に達 成できる限り低く保つための線源関連のプロセスあり， 防護の最適化は，一般的な事情の下で達成しうる最良策
が実施されたかどうか，また線量を低減するために合理 的であるようなすべてのことがなされたかどうかを問い かける，1つの心構えであると述べている。また，全関 係者による最適化のプロセスへの関与が必要であると し, 規制当局には焦点を, 具体的結果でなく, プロセス, 手法, 判断に当てることを求めている。

\section{2. 国際原子力機関(IAEA)の国際基準における防 護の最適化に係る要件}

IAEA の基本安全原則 ${ }^{5}$ においては, 原子力施設共通 に適用すべき10項目の原則を定める中で，施設と活動の 正当化(原則 4 )，個人に対するリスクの限度(原則 6 ), 現世代と将来世代の防護 (原則 7 ) とともに, 原則 5 ：防 護の最適化において，「合理的に達成できる最高レベル の安全を実現するよう防護を最適化しなければならな い。」ことを求めている。

このような安全原則を受けて, 放射性廃棄物の処分の 安全要件 ${ }^{6}$ においては, 線量基準の説明の中で, 拘束值 を組み込んだ最適化は, 廃裹物処分施設の放射線学的な 安全性を確保するために採用された中心的アプローチで ある。さらに，「防護の最適化は社会的および経済的因 子を考慮し, 定量的な解析の支援を受けつつ, 本質的に は定性的ではあるが構造化された手法で実施される判断 のプロセスである。」と説明し，定量的な評価よりも， 定性的な判断を優先した構造化されたプロセスであると 定義している。このような考え方は，ICRP の放射線防 護の新しい考え方に基づいている。

\section{3. 廃棄物合同条約における条項}

我が国をはじめ現時点で48ヶ国が加盟している使用済 燃料管理の安全および放射性廃棄物管理の安全に関する 合同条約においては，その第24条操業上の放射線防護に おいて，経済的および社会的要因を考慮して合理的に達 成可能な限り低く保つこと (ALARA)を求めている。こ 
のALARA の概念は現時点で，最も定着した概念であ り，後述するように各国の規制機関においても広く採用 されている。

\section{IN. 各国の安全規制における最適化}

各国の放射性廃裹物処分の安全規制における最適化の 考え方は必ずしも統一されたものでない。経済協力開発 機構/原子力機関 $(\mathrm{OECD} / \mathrm{NEA})$ の規制者フォーラムに おいても, 長期の不確かさを伴う処分システムの最適化 の考え方は重要な討議課題となっており，2009年に東京 で開催されたワークショップにおいても，ひとつの論点 として取り上げられだ)。これらを参考に, 各国の最適 化の考え方を第 3 表に示す。

ここに取り上げた各国の安全規制は先の ICRP の新勧 告の後に制定されたものであるが，米国とフランスを除 き，利用可能な最良の技術 (BAT: Best Available Technology)の適用や代替案との比較検討を要求するととも にプロセスを重視する傾向にあることがわかる。以下に この代表的な国の例を紹介する。

\section{1. スウェーデン}

スウェーデンの放射性廃裹物処分に対する指針等にお いては，最適化とBATを明文化する形で取り入れてい るが，その特徵は以下のように整理される。

・最適化の実施と BAT の適用の両方を明示

・最適化はリスク計算の結果に基づいてリスクを最小 にするためのツールと定義

・解析で重大な不確実性がリスク計算値に付随する場 合にはBATを重視
・両者間で矛盾が生じた場合には BATを優先

・BAT は多重バリアからの核種の放出抑制の措置に 重点

具体的には処分場開発の段階的プロセスにおいて， BATおよび最適化を評価し，これを反映した実施主体 の研究開発計画の審査によりその妥当性が政府決定され る。

\section{2. 英 国}

英国では浅地中処分および地層処分の許可要件のガイ ダンスともに，ALARAの考え方に沿った最適化やこれ を実現するための代替案との比較検討を重視している。 これまで, 英国ではBATのほかに, 環境の保護の観点 から「実行可能な最良の手段 (BPM: Best practicable means)」という概念が，原子力分野では「実行可能な最 良の環境オプション (BPEO: Best practicable environmental option)」という概念が適用されてきた。しかし, 上記のガイダンスの改正においては BATに置き換える ことが定められた。これは, BPM や BPEO が操業中の 定常的な環境への放出を抑制する手段に重点が置かれて いたのに対して，BATはライフサイクルすべてに対し て適用する概念であることおよび他国や英国内における 環境保護体制との整合性を高めるために実施されたもの である。具体的な BATの適用については，「放射性物 質規制：BATに関する評価」青に詳述されている。特に 重要な点は下記のような点である。

・最適化は管理オプションおよび適用する行為を選定 するために用いるプロセスであるとし, BPM, BPEO そして BAT はすべて同じプロセスを取り扱ったも

第 3 表 各国の放射性廃棄物処分の安全規制における最適化の考え方

\begin{tabular}{|c|c|c|}
\hline 国名 & $\begin{array}{c}\text { 放射性廃棄物処分における } \\
\text { 最適化の規制の主な内容 }\end{array}$ & 関連指針等 \\
\hline フランス & $\begin{array}{l}\text { ALARA と類似の一般的概 } \\
\text { 念のみ規定 }\end{array}$ & $\begin{array}{l}\text { ASN「地層におけるる放射性廃裹物の最終 } \\
\text { 処分に関する安全指針」(2008.2.12) の第 } \\
\text { 4. } 1 \text { 項 }\end{array}$ \\
\hline 英国 & $\begin{array}{l}\text { 最適化とBATを適用したプロセ } \\
\text { スを重視 }\end{array}$ & $\begin{array}{l}\text { EA他「浅地中処分施設の許可要件に関す } \\
\text { るガイダンス」(2009/2), 「地層処分施設 } \\
\text { の許可要件に関するガイダンス」(2009/2) } \\
\text { の原則 } 2 \text { 及ひ要件 } 8\end{array}$ \\
\hline $\begin{array}{l}\text { スウェ } \\
\text { ーデン }\end{array}$ & 最適化とBATの適用を要求 & 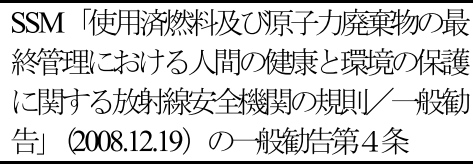 \\
\hline ドイツ & $\begin{array}{l}\text { 代替案との比較検討及び最 } \\
\text { 適化目標の各項目のバラン } \\
\text { スを重視 }\end{array}$ & $\begin{array}{l}\text { BMU「発熱性放身性廃裹物の最終処分に } \\
\text { 関する安全要件」(2009/7)の第5項 }\end{array}$ \\
\hline スイス & $\begin{array}{l}\text { 代替案との比較検討及びプ } \\
\text { ロセスの重視 }\end{array}$ & $\begin{array}{l}\text { ENSI「地層処分場の設計原則とセーフテ } \\
\text { イケースに関する要件」及び同解説 } \\
\text { (2009/4）の付属書 } 1 \\
\end{array}$ \\
\hline 米国 & $\begin{array}{l}\text { 被ばくを受ける世代と費用 } \\
\text { を負担する世代が乘離して } \\
\text { おり最適化を求めない }\end{array}$ & 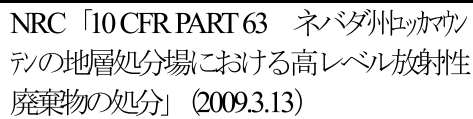 \\
\hline
\end{tabular}


ので，様々なオプションから選び取る判断のプロセ スであり，これらは等価である。

・認可済みサイト 1 ヶ所からの排出量全体において, 想定される線量が $10 \mu \mathrm{Sv} /$ 年より低い場合，現在設 定されている排出限度のさらなる引き下げを求める ことはない。

また，この10 $\mu \mathrm{Sv} /$ 年という值は，線量目標值でも， 線量限度でも, しきい值でも, 放射線基準でもなく, こ の值は単に，運転/操業者が今後も BATの適用を継続 した場合に，それより低ければ排出限度の引き下げを行 う必要のない適切な線量のレベルの一つを示したものと し，この值をこれまで使用してきた $20 \mu \mathrm{Sv} /$ 年という「最 適化のためのしきい值」の代わりとして採用すべきと提 案している。

\section{V．放射性廃棄物処分の最適化の要件と 処分システムの頑健性確保の方策}

\section{1. 最適化の方向性とその要件}

放射性廃棄物処分に係る防護の最適化，特に管理期間 終了後の長期安全性に係る最適化は国際的にもいまだ多 くの議論が行われているが，IAEAの基本安全原則 ${ }^{5} や$ 廃裹物合同条約に見るように，最適化とALARAの概 念はほぼ同意語として使用されており，多くの国で放射 性廃棄物処分にも適用されている。これを実現するため のひとつの方策として，将来世代が受ける可能性のある 集団線量の定量的最適化から，BAT 等の適用による処 分システムの頑健性確保のための定性的判断のプロセス が，スウェーデンや英国において最適化の柱となってき ている。

このような背景のもと, IAEA の安全要件 ${ }^{6}$ や ICRP の新衔告 ${ }^{4)}$ 踏まえると, 我が国においても最適化の概
念を下記のような要件を備えた線源関係のプロセスとし て定義するのが妥当である。

・合理的に達成できる限り低く保つための判断のプロ セス

・構造化されたプロセス

・透明性・公平性があるプロセス

少なくとも，放射性廃棄物処分の放射線防護の最適化 は，遠い将来世代の被ばくを対象にしたものであり，そ の最適化の成果が直近の世代に現れることはない。この ため試行錯誤により最適解が得られるものでもない。し たがって，実施主体の努力任せの一般的な概念規定では なく，透明性がある構造化された判断のプロセスである ことが必須である。これらの要件は他の原子力施設と異 なり，処分施設の安全性を実時間，実規模で実証するこ とが不可能であり，常に，可能な限り少しでもより良い ものを求める心構えに依拠せざるを得ないことに基づい ている。

安全審査の基本的考え方 (改訂)においても，ALARA の規定や BAT の適用および新しい技術的知見を反映し た評価の更新等が規定されており，最適化に係わる考え 方の骨格は取り入れられているものと考えられる。これ らをまとめて第 4 表に示す。

\section{2. 処分システムの頑健性確保と今後の展望}

既述の安全審査の基本的考え方 (改訂) が整備されたこ とを踏まえると，今後，展開すべき議論は，長期的不確 かさを考慮してBAT 等を適用した処分システムの頑健 性確保のための具体的な方策に関するものである。これ を代替選択肢との比較検討を含めたすべての側面を考慮 した体系的なプロセスにするとともに，最善策を追求す る安全文化に支えられたプロセスにするための議論であ

第 4 表 最適化の一般的要件と安全審査の基本的考え方(改訂)における整備状況

\begin{tabular}{|c|c|}
\hline 最適化の一般的要件 & $\begin{array}{c}\text { 安全審査の基本的考え方（改訂） } \\
\text { における整備状況 }\end{array}$ \\
\hline $\begin{array}{l}\text { 合理的に達成できる限り低く保つ } \\
\text { ための判断のプロセス } \\
\text { •定量的な解析に支援されつつも定 } \\
\text { 性的な判断を重視したプロセス } \\
\text { •長期的不確かさを考慮しBATを優 } \\
\text { 先したプロ }\end{array}$ & $\begin{array}{l}\text {-ALARAの規定 (4基本的安全対策の本文) } \\
\text { - BATの一般的概念適用 (4.1移行抑制の } \\
\text { ·代替選択肢との比較評価については未 } \\
\text { 規定 } \\
\text { • 判断に対する頑健性の要求 (8.3管理 } \\
\text { 期間終了までの評価の更新の解説) }\end{array}$ \\
\hline $\begin{array}{l}\text { 構造化されたプロセス } \\
\text { •全ての側面を考慮した体系化され } \\
\text { たプロセス } \\
\text { •段階的かつ反復的な意思決定に反 } \\
\text { 映するプロセス }\end{array}$ & $\begin{array}{l}\text { •その時点の最新の知見を反映した長期 } \\
\text { 的な安全評価の更新を要求 (8.3管理期 } \\
\text { 間終了までの評価の更新の解説) } \\
\text { ·全ての側面を考慮した体系化されたプ } \\
\text { ロセスについては未規定 }\end{array}$ \\
\hline $\begin{array}{l}\text { 透明性・公平性があるプロセス } \\
\text { •利害関係者が関与できるプロセス } \\
\text { •最善策を追求する安全文化に支え } \\
\text { られたプロセス }\end{array}$ & $\begin{array}{l}\text { •公開の委員会等にて討議し、利害関係 } \\
\text { 者のパフフリックコメント等を反映して } \\
\text { 必要に応じて見直し } \\
\text { ・品質保証に関する要件のみ規定。安全 } \\
\text { 文化については実施主体の自主的取り } \\
\text { 組みに期待 }\end{array}$ \\
\hline
\end{tabular}


る。

処分システムの頑健性を確保するためには, 被ばくシ ナリオに対する安全確保の全体構造を概観し，留意すべ き重要事項を把握し，これに対して BATを適用するこ とが核心である。このような観点から，影響する要因を 分析すると, 被ばく線量は 4 つの因子, すなわち廃異物 に含まれる総放射能量, 人工バリアの防護機能, 天然バ リアの防護機能および生活圈での人への線量換算係数の 関数として表現できる。これらの 4 つの因子の中で, 被 ばく線量に及ぼす影響の観点から，何が最も重要であ り，管理可能であるかを分析することにより，頑健性確 保のために適用すべき BAT も明らかになってくる。管 理可能な人工バリアの代表的な防護機能は, 廃棄体容器 の閉じ込め機能掞よび人工バリアの移行抑制機能であ り，離隔とともに放射性廃棄物処分の安全確保の柱をな すものである。閉じ込めの機能を高めることは，それ以 降の多くの不確かさの影響を低減できるBATの適用の 重要な対象である。この閉じ込め機能に期待する期間は 埋設する廃裹物の放射能の減衰特性に応じて変わり, 長 半隇期核種を有意に含む場合には，より長期にわたり機 能維持が求められる。

\section{V.おわりに}

第 2 種廃棄物埋設の事業に対する安全評価に関する考 え方の骨格は定まったが，その具体的な適用はこれから である。

過去におけるBATの調查研究的においても,「BAT は Moving Targetであり，実施主体は常にこれに接近 する不断の努力を惜しまないという姿勢を内外に示し続 けることが必要」と述べられている。放射性廃棄物処分 の長期的な安全確保に係る科学的・合理的解決策を見出 すため, さらには国民の安全・安心感を醹成していくた めにも，防護の最適化のプロセスの確立は必須である。 このプロセスは, ALARAを追求し, 構造化され, 透明 性・公平性があるプロセスとして, 具体的な運用方法が 定着することが期待される。このためには，実施主体の ALARA を追求する安全文化に加え, 長期的な不確かさ の影響を出来る限り回避あるいは軽減する処分システム の頑健性を常に求め続ける構造化されたプロセスの確立 が重要である。更には透明性・公平性があるプロセスと して，例えば，頑健性確保に繋がる幅広い利用可能な技 術や利害関係者の提案等も取り入れた代替選択肢との比 較評価を中心として BAT を適用するプロセスが有効と 思われる。これらのプロセスに係るガイドライン策定に 向けて, 学会での議論を樑めて頂きたいと思う。

\section{一参 考 資 料一}

1) A. Suzuki, An Overview on Radioactive Waste Disposal Regulations in Japan - The Status Quo and the Future Directions, NSC, prepared for a meeting with USNRC/ ACNW, May 16, 2005.

2) ICRP Publ. 77, 放射性廃棄物の処分に対する放射線防護 の方策, (1998).

3）ICRP Publ. 101，公衆の防護を目的とした代表的個人の 線量評価・放射線防護の最適化：プロセスの拡大, (2007).

4）ICRP Publ. 103, 国際放射線防護委員会の2007年勧告, (2007).

5) IAEA, Fundamental Safety Principle, Safety Fundamentals No. SF-1, (2006).

6) IAEA, Disposal of Radioactive Waste, Draft specific safety requirements No. SSR-5, DS 354, (2009).

7) OECD/NEA, Towards Transparent and Deliverable Regulation for Geological Disposal-Main Findings from the RWMC Regulators' Forum Workshop, Tokyo, 20-22 January 2009, NEA/RWM/RF, 1 (2009).

8 ) Environment Agency, Radioactive Substance Regulation: Assessment of Best Available Technology (BAT), GEHO 0709 BQTA-E-E, (2009).

9）杉山大輔, 他, 放射性廃棄物処分における「技術的に最 善の手段(BAT)」の考え方一諸外国事例のレビューとわ が国への示唆, 電力中央研究所報告, 調査報告: L 06001, (2006).

著者紹介

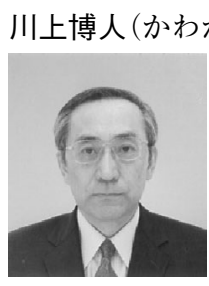

ひろと)

原子力安全基盤機構

放射性廃棄物・廃止措置専門部会 (専門分野/関心分野) 放射性廃棄物処分, 廃止措置他

青木広臣(あおき・ひろおみ)

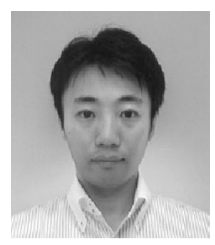

原子力安全基盤機構

(専門分野/関心分野)放射性廃棄物処分, 計算力学

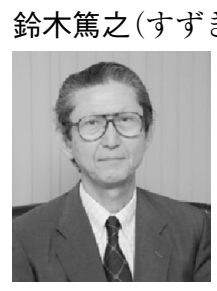

